\title{
The Role of Positive Framing in the Relationship between Career Commitment and Career Success
}

\author{
R. James \\ Department of Human Resources Management, University of Jaffna \\ robinson435@gmail.com
}

Received: 28 October 2020

Accepted: 30 November 2020

\begin{abstract}
Individual-level resources that energize individuals have become more critical than before for career success. This study aims to investigate the influence of career commitment on career success and the moderating role of positive framing on the relationship between career commitment and career success. This study included 159 responses drawn from private financial institutions in Sri Lanka. This study adopted a quantitative approach and employed hierarchical multiple regression to analyze the data. The results indicated that respondents' profile data did not significantly influence career success, but career commitment and positive framing positively influence career success. Further, this study explored that employees' engagement in positive framing moderate the relationship between career commitments and career success, it indicates that this relationship is more vital for those who engage in a high level of positive framing than those who engage in the low level of positive framing. Career commitment and positive framing together explain $60 \%$ of the variance in career success. This is the first study that examines the subject of positive framing on the relationship between career commitment and career success. By identifying the moderator role of positive framing, this study extends our understanding of the role of positive framing in career research. This study suggests the
\end{abstract}


significant role of individuals in their career success. The results of this study advise the employees to develop their personal career goals and involve in these goals. In addition to the career commitment, employees are advised to develop their self-management process in an optimistic way to achieve their career success.

Keywords: Self-management, Positive Framing, Career, Career Commitment, Career Success

\section{Introduction}

Both employees and employers are fascinated to know why some people are more successful in their careers than others. The emergence of new career models (boundaryless or protean careers) claims that careers are not limited to organizational boundaries, and employees are responsible for their self-interested careers (Arthur et al., 2005; Sultana et al., 2016). The current career environment forces employers to select people with transferable skills that help them to perform successfully in the emerging career context (Ballout, 2009). Also encourage individuals to self-manage their career than depend on their organizations' directions for their career success. Therefore, employees are encouraged to develop their transferable skills and commit to their careers than to their organization for their career success (Ballout, 2009; Sultana et al., 2016).

Career commitment is described as "one's attitude toward one's profession or vocation" (Blau, 1985: 278) it reflects the motivation of people to work toward personal development in their profession (Ellemers et al., 1998). Employees who highly committed to their careers are inclined to make excellent investments in their careers and put considerable effort in achieving their career goals. Career commitment is positively related to satisfaction, skill development, and career success (Vandenberghe and Ok, 2013; Pasha et al., 2017; Sultana et al., 2016). Career success is the collection of accomplishments stem from the work experiences (Judge, Cable, Boudreau, \& Bretz, 1995) and it is a path of satisfying individuals' need for attainment and power in their career paths (Ishak, 2015). Career success consists of two dimensions: objective career success Peradeniya Management Review - Volume II Issue 1 (June) 2020 
and subjective career success (Ballout, 2009; Seibert et al., 1999; Spurk et al., 2019). Though objective career success relates to visible career achievements, subjective career success relates to lessobservable career achievements (Ballout, 2009). Subjective career success is an individual's feelings of attainments and enjoyment with his/her career (Judge et al., 1995). Subjective career success is more likely to enhance individuals' happiness, and it leads to objective career success in the future (Abele and Spurk, 2009; Nabi, 2003).

The emerging career theories claim that organizational borders do not limit careers, but it is within the control of individuals (Arthur et al., 2005; Lyons et al., 2015). Consequently individual-level resources that energize them have become more critical than before for career success. Positive framing is a cognitive self-management process that helps individuals to feel positive energy (Ashford and Black, 1996; Owens, 2010; Ashford and Taylor, 1990; James, 2019). Individuals who engage in positive framing favorably interpret the environments: they explain the situation as an opportunity rather than thread though the actual situation prevails as it is, and such interpretations increase their resources. Further, as a resource, positive framing increase employees' psychological capital (Gruman and Saks, 2013), which is a positive psychological characteristic include self-efficacy, optimism, hope, and resilience (Luthans et al., 2006). Unfortunately, scholars failed to identify the role of positive framing in careerrelated research. However, Judge, Cable, Boudreau, \& Bretz, (1995) found that human capital is an antecedent of career success. Extensive studies suggest that Career commitment is a crucial determinant of career success. In the modern career context, that is dynamic and individual goal-oriented, cognitive self-management of individuals can be imperative for career success in addition to the career commitment. Further, Ballout (2009) suggested that future research can include variables that can strengthen the positive influence of career commitment on career success. Positive framing has the potential to reinforce the positive impact of career commitment on career success. Therefore, this study aims to investigate the positive influence of career commitment on career success and the moderating effect of positive framing on the positive 
relationship between career commitment and career success. Studying the moderator role of positive framing on the relationship between career commitment and career success will enlarge the understanding of the role of positive framing on career research. This study is also the first to examine the subject of positive framing on the relationship between career commitment and career success. Further, this study examines the said relationships in Sri Lankan context, where there is a lack of researches in this study area.

Previous studies suggest that compared to objective measures, subjective measures of career success relates to more positive career outcomes (Gattiker and Larwood 1986; Karavardar, 2014; Kim and Beehr, 2017). Also, Park (2010) noted that in the modern career context where uncertainty and mobility of the career have become an inevitable part assessing career success in terms of subjective indicators is more meaningful. Further, Subjective career success leads to individuals' happiness and objective career success in the future (Abele and Spurk, 2009; Ballout, 2009; Nabi, 2003). Therefore, this study considers only subjective career success.

\section{Literature Review and Hypotheses Development}

\subsection{Career Commitment}

The term 'career' has been defined in a different point of views. Generally, a career can be defined as an individual's role-related lifelong sequence of experiences (Hall, 2002). According to Greenhaus (1987), a career is a series of jobs held during an individual's lifetime. The dynamic nature of career and career context encourage individuals to self-manage their career and be more committed to their career than to their organization (Ballout, 2009; Sultana et al., 2016). Hall (1971: 59) describes career commitment as "the strength of one's motivation to work in a chosen career role". Many career scholars have described career commitment as an attitude, for example, Hall (1976) and Mueller et al., (1992) describe career commitment as an identification with and involvement in one's profession. Similarly, Blau (1988) describes career commitment as 'one's attitude towards one's profession or vocation'. Career 
commitment as an attitude includes personal career goals and identification and involvement in these goals. Career commitment differs from organizational commitment. Organizational commitment involves an individual's identification with and involvement in a particular organization" (Mowday et al., 1979). In contrast, career commitment includes self-generated goals and identification and attachment with one's career. Randall, (1987) highlights that organizational context and nature of the career leads to one's career commitment and possibly less or provisional commitment to their organizations. Individual disparities and situational factors are the key antecedents of career commitment London (1983). Literature suggests that employees' career commitment positively related to job satisfaction, skill development, career investment, and career success (Vandenberghe and Ok, 2013; Ballout, 2009; Pasha et al., 2017; Sultana et al., 2016). In the same way, Day and Allen (2004) found career commitment enlarges career satisfaction.

\subsection{Career Success}

Career success is "the experience of achieving goals that are personally meaningful to the individual, rather than those set by parents, peers, an organization, or society" (Mirvis \& Hall, 1994). According to Judge et al. (1995), it is the collection of attainments stem from the work experiences. Similarly, Seibert and Kraimer (2001) label career success as the added positive work and psychological consequences arising from one's work experiences. Ishak (2015) noted that career success is a way of satisfying individuals' need for attainments and power in their career paths. Career success is viewed as both subjective and objective perspectives (Baruch 2004; Breland et al., 2007; Judge et al., 1995; Spurk et al., 2019). According to Judge et al. (1995), career success is an individuals' objective or subjective perception of achievements in their work experiences. Researchers have identified conceptual differences between objective and subjective career success ( $\mathrm{Ng}$ et al., 2005; Seibert et al., 1999). 
While Objective career success includes visible career attainments such as promotion, different job titles and salary, subjective career success includes unobservable achievements such as job satisfaction, work-life balance, and career satisfaction (Ballout, 2009; Nabi, 1999). Seibert \& Kraimer (2001) describes subjective career success as an individuals' assessment of their career advancement and expected results, connected to their own goals and aspirations. Subjective career success is an individual's feelings of attainments and enjoyment with his/her career (Judge et al., 1995). Objective career success involves extrinsic career results which may not satisfy an individual (Kim and Beehr, 2017). Compare to objective measures, subjective measures of career success relates to more positive invisible career outcomes (Gattiker and Larwood 1986; Karavardar, 2014). They suggest that subjective career success involves an individual's disposition for improvement in a selected profession.

Further, the modem dynamic career context forces individuals to selfmanage their career than depend on their organizations' directions for their career for success. It is suggested that objective career success is the consequences of subjective career success (Judge et al., 1995; Karavardar, 2014). In a similar manner, Way et al. (1981) suggest that subjective career success may not depend on objective career success indicators. In the modern career context where uncertainty and mobility of a career has become an inevitable part assessing career success in terms of subjective indicators is more meaningful (Park, 2010).

\subsection{Career Commitment and Career Success}

Literature has highlighted the association between career commitment and career success (Pasha et al., 2017; Poon, 2004; Sultana et al., 2016). Both organizational commitment and career commitment are strongly related to career success (Kidd and Green's study (2006). Ballout (2009) found that subjective career success is an essential outcome of career commitment. Similarly, Carson, Roe, Birkenmeier and Philips (1999) found that career commitment 
positively influences career success. In a study, Poon (2004) uncovered that both subjective and objective career success are strongly determined by career commitment.

In the same way, Sultana et al. (2016) found that both subjective and objective career success was positively influenced by career commitment. Further, Ballout (2009) found the positive influence of career commitment on both subjective and objective career success and the moderating effect of self-efficacy on this relationship. A study on newcomers found that career/occupational commitment has a positive influence on job/career satisfaction (Wang et al. (2016). Similarly, Pathardikar et al. (2016) found that career commitment positively influences subjective career success (satisfaction). The majority of the studies related to career commitment and career success were conducted in different context expect in Sri Lankan context. Therefore, this study assumes that career success will be the consequences of career commitment will have a positive influence in Sri Lankan context. Therefore, this study proposed that:

H1: Career commitment positively influences career success.

\subsection{The Moderating Role of Positive Framing}

A considerable number of studies have found a positive influence of career commitment on career satisfaction (Karavardar, 2014; Punnett et al., 2007). Nevertheless, only a few studies investigated the moderator effect of individual-level variables on this relationship. Ballout (2009) investigated the moderating effect of self-efficacy on the relationship between career commitment and career success. They found that the positive relationship between career commitment and career success (both objective and subjective) has been moderated by self-efficacy. Poon (2004) examine the moderating role of emotion perception on the relationship between career commitment and career success and found emotion perception did not function as moderator. Today's dynamic nature of the career environment encourages individuals to self-manage their career rather depend on their organizations' directions for their career success (Ballout, 2009; Sultana et al., 2016). 
People tend to be involved in self-control or self-management to develop control in various circumstances (Ashford \& Black, 1996). Positive framing can be described as a cognitive self-management process that enables individuals to increase learning and reduce uncertainty and stress (Ashford and Black, 1996; Owens, 2010; Saks and Ashforth, 1996). It involves explaining events in an optimistic way that helps individuals to feel positive energy (Ashford and Taylor, 1990; James, 2019). By interpreting the situation and activities as an opportunity, positive framing enables individuals to increase their resources though the actual situation is as it is. Positive framing increases one's self-confidence and self-efficacy (Ashford \& Black, 1996; Griffin et al., 2001), which are personal resources (Saks \& Gruman, 2012). Such own resources help individuals to assimilate more resources and overcome stress and challenges (Hobfoll, 2002; Saks \& Gruman, 2012). A considerable number of studies claimed that positive framing leads to favourable socialization outcomes such as social integration, job satisfaction, job performance and employee retention (Ashford and Black, 1996; Gruman et al., 2006; Kim et al., 2005; Kowsikka \& James, 2019; Wanberg and Kammeyer-Mueller, 2000). Further, as a positive resource framing increase employees' psychological capital (Gruman and Saks, 2013). Psychological capital is a positive psychological characteristic includes selfefficacy, optimism, hope, and resilience (Luthans et al., 2006). Judge et al. (1995) found that human capital is an essential element of career success. In the present context where career patterns are dynamic, individual goal-oriented and boundary-less, which requires individuals to take responsibility for their career development (Ballout, 2009; Lyons et al., 2015). Therefore, individual-level resources that energize individuals has become essential for career success than before. The influence of career commitment on employees' career success may differ in terms of their positive framing levels. Specifically, it is believed that a high level of positive framing usage will strengthen the positive relationship between career commitment and subjective career success. Therefore, this study proposes the following hypotheses: 
H2a: Positive framing moderate the positive influence of career commitment on career success.

H2b: Higher positive framing levels entail a stronger relationship between career commitment and career success, while lower levels of positive framing lead to a weaker association between career commitment and career success.

\section{Research Methodology}

\subsection{Participants}

The population of this study were employees working in private sector financial institutions in Sri Lanka. Three hundred employees from 22 organizations in the financial sector have been invited to the survey. Minimum of 10 participants were invited from the each selected institution. As there is a significant difference in the availability of career advancement opportunities between private and public sector organization researcher has focused only the private sector, particularly the financial institutions. The researcher sent the survey pack to the selected participants through his visit and personal network. To maintain confidentiality and anonymity, researcher avoided collecting personal data that might identify the particular respondent. The self-addressed cover was issued to each participant, and they were advised to post the survey directly to the researcher's address without mentioning their personal information. Out of 300 surveys issued, only 168 (56\%) were returned. Nine questionnaires were removed from the data set because of the high percentage of a missing point per variable (more than 15\%), and thus ultimately this study was conducted with 159 (53\%) responses. The respondents' profile is shown in table 1.

\subsection{Measures}

Career commitment: Career commitment that describes 'one's attitude towards one's profession or vocation' (Blau (1988) has been 
assessed with the 17-items scale developed by Colarelli and Bishop (1990). Previous studies (Colarelli \& Bishop, 1990; Ballout, 2009) and the current study found an acceptable reliability coefficient, Cronbach's alpha was more generous than .7. Sample item includes, "I am willing to put in a great deal of effort beyond that normally expected in order to be successful in this career."

Career success: This study considers only subjective career success because a) compared to objective measures, subjective measures of career success relate to more positive career outcomes (Gattiker and Larwood 1986; Karavardar, 2014; Kim and Beehr, 2017), b) in the modern career context assessing career success in terms of subjective indicators is more meaningful (Park, 2010).

It was assessed through a five-item scale developed by Greenhaus et al. (1990). Previous studies (Greenhaus et al., 1990; Ballout, 2009) and the current research has reported an acceptable reliability coefficient. Sample item: "I am satisfied with the success I have achieved in my career."

Positive framing: Positive framing that involves explaining events in a positive way that helps individuals to feel positive energy (Ashford and Black, 1996; Owens, 2010; James, 2019) was assessed with three items scale developed by Ashford and Black's (1996). Previous studies (Ashford\& Black, 1996; James 2020: Kim et al., 2005) and the current have shown excellent reliability scores (Cronbach's alpha $>$.8). The scale includes items like "I tried to see my situation as an opportunity rather than a threat." For each scale, respondents answered each question on 5-point Likert-type scales, with the response ranging from $1=$ strongly disagree to $5=$ strongly agree.

\subsection{Data Analysis Procedure}

The data entered in Microsoft Excel sheet has been transferred to SPSS 20 for data cleaning and examination. After the data cleaning process, validity and reliability of the data were assessed. Finally, the proposed relationships have been assessed via hierarchical regression analysis. Also, this study, assess the influence of respondents' profile data (Gender, marital status, age, work experience and management 
levels) on career success by controlling them when the primary and moderating effect of the variables were assessed through hierarchical multiple regression analysis.

As the proposed model was not complicated and have only one dependent variable researcher employed hierarchical regression analysis instead of structural equation modelling. However, the researcher assessed the reliability and validity via widely accepted statistics and reported them (See Table 3).

\section{Data Analysis and Results}

\subsection{Data Analysis Process}

During the data cleaning process questionnaire non-responsive rate, item non-response rate, distribution of data and outliers were checked, a few deviations were observed, and they were treated properly. Missing points were replaced with mean value except the nine response removed because of a large number of missing points.

\subsection{Respondents' Profile}

First, the respondents' profile in terms of their gender, marital status, age, work experience, and management level, were analyzed and tabulated in Table 1 below.

Table 1: Respondents' Profile

\begin{tabular}{|l|l|l|l|}
\hline \multicolumn{2}{|l|}{ Respondents' Profile } & Number & Percentage \\
\hline \multirow{2}{*}{ Gender } & Male & 84 & $53 \%$ \\
\cline { 2 - 4 } & Female & 75 & $47 \%$ \\
\hline \multirow{2}{*}{ Marital status } & Single & 46 & $29 \%$ \\
\cline { 2 - 4 } & Married & 113 & $71 \%$ \\
\hline \multirow{2}{*}{ Age } & $\begin{array}{l}\text { Below } 35 \\
\text { years }\end{array}$ & 45 & $28 \%$ \\
\cline { 2 - 4 } & $36-50$ years & 67 & $42 \%$ \\
\cline { 2 - 4 } & $\begin{array}{l}\text { Above 50 } \\
\text { years }\end{array}$ & 47 & $30 \%$ \\
\hline Work & Less than 10 & 25 & $16 \%$ \\
\hline
\end{tabular}




\begin{tabular}{|l|l|l|l|}
\hline \multirow{4}{*}{ experience } & years & & \\
\cline { 2 - 4 } & $11-20$ years & 89 & $56 \%$ \\
\cline { 2 - 4 } & $\begin{array}{l}\text { More than } 20 \\
\text { years }\end{array}$ & 45 & $28 \%$ \\
\hline \multirow{2}{*}{$\begin{array}{l}\text { Management } \\
\text { level }\end{array}$} & Low & 21 & $13 \%$ \\
\cline { 2 - 4 } & Middle & 118 & $74 \%$ \\
\cline { 2 - 4 } & Top & 20 & $13 \%$ \\
\hline
\end{tabular}

Majority of the participants were male, accounted for $53 \%(n=84)$. Twenty-nine percent of respondents $(n=46)$ were unmarried. Regarding age, majority of the respondents ( $\mathrm{n}=67,42 \%)$ were between the age group of 36 and 50 whereas only $28 \%$ and $30 \%$ were below 35 years old and above 50 years of old category respectively. Majority of the participants $(n=89,56 \%)$ possess $11-20$ years of experience, whereas only a few respondents (16\%) had less than ten years of experience. The high percentage of the respondents (74\%) were in a middle-level management position, and the relatively same percentage of respondents (13\%) were in both top and bottom level management position in their respective organizations.

\subsection{Reliability and Validity}

Factor loading of each item of the three constructs were greater than 0.6 that indicates the acceptable indicator reliability (Hair et al., 2011, 2017). Construct reliability was assessed through both Cronbach's alpha (CrA) and composite reliability (CR) which were much higher than the expected value of 0.7 (see table 2). The average variance extracted (AVE) was used to assess the construct validity that describes to what extent an indicator of the construct correlates with alternative measures of the same construct (Hair et al., 2011). AVE of each construct (career commitment $=0.69$, career success $=0.67$, positive framing $=0.64$ ) was greater than the threshold value of 0.5 (Hair et al., 2011, 2017). 
Table 2: Mean Std. CrA, CR and AVE of the Main Constructs

\begin{tabular}{|l|l|l|l|l|l|}
\hline Constructs & Mean & Std. & CrA & CR & AVE \\
\hline $\begin{array}{l}\text { Career } \\
\text { Commitment }\end{array}$ & 2.31 & 1.01 & 0.88 & 0.91 & 0.69 \\
\hline Positive Framing & 3.31 & .96 & 0.81 & 0.87 & 0.64 \\
\hline Career success & 2.48 & 1.07 & 0.87 & 0.91 & 0.67 \\
\hline
\end{tabular}

The correlations between the variables were tabulated in Table 3 . There are significant correlations among respondents' profile variables. Still, no significant associations were observed between respondents' profile variables and the main variables of the current study (career commitment, career success, and positive framing). Mean stranded deviation and correlation among variables found to be reasonable (see Table $2 \& 3$ ).

Table 3: Correlations between Respondents Profile, Career Commitment and Career Success

\begin{tabular}{|l|l|l|l|l|l|l|l|}
\hline Variables & $\begin{array}{l}\mathbf{1} \\
\mathbf{( S e x})\end{array}$ & $\mathbf{2}$ & $\mathbf{3}$ & $\mathbf{4}$ & $\mathbf{5}$ & $\mathbf{6}$ & $\mathbf{7}$ \\
\hline Marital_St (2) & $.186^{*}$ & 1 & & & & & \\
\hline Age (3) & -.065 & $.740^{* *}$ & 1 & & & & \\
\hline Work Exp. (4) & $-.318^{* *}$ & $.549^{* *}$ & $.619^{* *}$ & 1 & & & \\
\hline Mgt. Levels (5) & $.210^{* *}$ & $.538^{* *}$ & $.570^{* *}$ & $.383^{* *}$ & 1 & & \\
\hline Career Com (6) & -.020 & .025 & .064 & .046 & .034 & 1 & \\
\hline $\begin{array}{l}\text { Positive Fram } \\
\text { (7) }\end{array}$ & -.019 & -.018 & .070 & .049 & .096 & $.170^{*}$ & 1 \\
\hline Career Succ (8) & .044 & .013 & -.010 & -.010 & .108 & $.582^{* *}$ & $.220^{* *}$ \\
\hline
\end{tabular}

*. Correlation is significant at the 0.05 level (1-tailed). **. Correlation is significant at the 0.01 level (1-tailed). 


\subsection{Hypotheses Testing}

The researcher employed Hierarchical multiple regression to test the proposed three hypotheses; in the first step, the control (respondents' profile) variables were entered. Predictor variable (career commitment) and moderator variable (positive framing) were introduced in the second and third steps, respectively. Finally, the interaction term (career commitment $*$ positive framing) was entered (Aiken and West, 1991). This process created four regression model, and it is presented in Table 4.

The results showed that no control variables- gender, marital status, age, work experience and management levels have a significant influence on career success. Further, the results indicated that career commitment has positive $(\beta=0.56)$ and significant $(p=0.00)$ impact on career success at 0.01 significant levels (see Table 4, model 2). Career commitment alone explains $28.1 \%\left(\mathrm{R}^{2}=28.1 \%\right)$ of the variance in career success. This result indicated that employees with high career commitment are more likely to succeed in their subjective career. Therefore, the first hypothesis that career commitment positively related to career success has been accepted. As shown in Table 4 (Model 3) the moderator variable has a positive impact $(\beta=$ 0.15 ) on career satisfaction, but this impact is not significant $(\mathrm{p}=$ 0.03 ) at 0.01 significant levels when the predictor variable in the model, however, it is significant at 0.05 significant levels.

The interaction term was introduced into the model to test the moderator effect of positive framing on the positive relationship between career commitment and career success. Results indicated (Model 4) that interaction term has positive impact $(\beta=.17)$ and its $t-$ statistics $(t=2.66)$ is significant $(\mathrm{p}=0.00)$ at 0.01 significant levels. The results suggest that positive framing moderate the positive relationship between career commitment and career success, and thus the hypothesis $\mathrm{H} 2$ (a) has been supported. 
Table 4: Outcomes of Hierarchical Regression Analysis

Dependent variable- subjective career success

\begin{tabular}{|c|c|c|c|c|c|c|c|c|c|c|c|c|}
\hline \multirow{2}{*}{$\begin{array}{l}\text { Varia } \\
\text { bles }\end{array}$} & \multicolumn{3}{|c|}{ Model 1} & \multicolumn{3}{|c|}{ Model 2} & \multicolumn{3}{|c|}{ Model 3} & \multicolumn{3}{|c|}{ Model 4} \\
\hline & $\bar{\beta}$ & $\mathbf{t}$ & Sig. & $\beta$ & $\mathbf{t}$ & Sig. & B & $\mathbf{t}$ & Sig. & B & $\mathbf{t}$ & Sig. \\
\hline $\mathrm{Ag}$ & 9 & $\underset{.}{ \pm}$ & શิ & $\stackrel{0}{?}$ & 후 & $\bar{m}$ & $\because$ & $\underset{\sim}{8}$ & $\bar{n}$ & $\stackrel{m}{\longrightarrow}$ & $\infty$ & $\stackrel{\infty}{?}$ \\
\hline Ex & $\stackrel{\infty}{\infty}$ & $\underset{i}{\text { f }}$ & ర․ & $\stackrel{?}{?}$ & $\hat{\sigma}_{i}$ & qे & $\stackrel{\infty}{\infty}$ & ?ִ & $n$ & $\stackrel{?}{?}$ & $\mathscr{n}_{i}^{n}$ & $\vec{n}$ \\
\hline Ma_St & 2 & 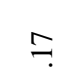 & $\infty$ & $8_{i}$ & $\overbrace{i}$ & $\hat{a}$ & $\overbrace{i}$ & $\underset{i}{ \pm}$ & $\infty$ & $\delta_{i}$ & $g_{i}$ & ๙ุ \\
\hline $\begin{array}{l}\text { Mgt- } \\
\text { Lev }\end{array}$ & $\underset{i}{\text { q }}$ & $\stackrel{\infty}{\circ}$ & ?ุ & $\stackrel{⿱}{i}$ & $\stackrel{n}{?}$ & ב & ก & $\stackrel{\Upsilon}{\rightarrow}$ & กิ & Э & $\stackrel{\circ}{\circ}$ & तै \\
\hline Sex & $\stackrel{0}{?}$ & $\stackrel{\infty}{r}$ & $\stackrel{?}{f}$ & $\stackrel{m}{m}$ & $\stackrel{1}{2}$ & ㅇ․ & \pm & 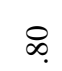 & $\stackrel{\Upsilon}{乛}$ & $\stackrel{0}{-}$ & ธุ & ? \\
\hline $\mathrm{CC}$ & & & & 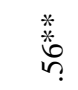 & $\stackrel{\infty}{\sim}$ & 8 & $\stackrel{*}{*}$ & $\stackrel{\circ}{\sim}$ & 8 & $\hat{s}_{i}$ & $\stackrel{\overbrace{}}{~}$ & $?$ \\
\hline PF & & & & & & & $\stackrel{*}{6}$ & $\underset{i}{\stackrel{O}{i}}$ & o. & 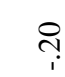 & $\stackrel{m}{\rightarrow}$ & $\stackrel{\infty}{\longrightarrow}$ \\
\hline $\mathrm{CC} * \mathrm{PF}$ & & & & & & & & & & $\stackrel{*}{\stackrel{*}{*}}$ & $\stackrel{o}{i}$ & 8 \\
\hline
\end{tabular}

Model summary statistics

\begin{tabular}{|l|l|l|l|l|}
\hline $\mathrm{R}^{2}$ & .170 & .556 & 574 & .599 \\
\hline $\begin{array}{l}\text { Adjust. } \\
\mathrm{R}^{2}\end{array}$ & .029 & 309 & .329 & .359 \\
\hline$\Delta \mathrm{R}^{2}$ & .029 & $.281^{* *}$ & $.020^{*}$ & $.030^{* *}$ \\
\hline$\Delta \mathrm{F}$ & .907 & 61.739 & 4.410 & 6.940 \\
\hline Sig. $\Delta \mathrm{F}$ & .478 & .000 & .037 & .009 \\
\hline
\end{tabular}

To illustrate how the change in the positive relationship between career commitments levels of respondents (high, low) and career success when the moderator variable of positive framing is low and high, a simple slope analysis was performed (Aiken and West. 1991). Figure 1 below gives a descriptive plot showing these interactions. 


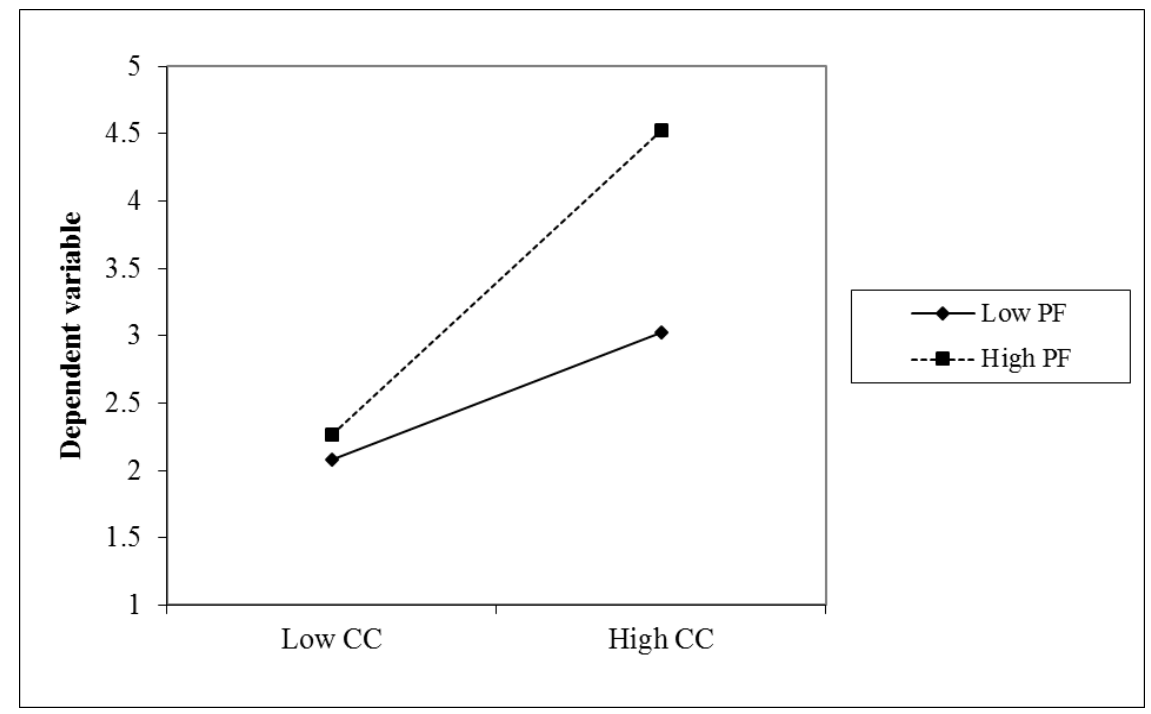

Figure 1: Relationship between Career Commitment and Career Success at High and Low Levels of Positive Framing

The figure indicates that career success is almost the same for the respondents who engage in a high or low level of positive framing when career commitment is low. Career success is higher for those who engage in a high level of positive framing than who engage in a low level of positive framing when career commitment is high. The slope of the curve suggests that higher positive framing levels entail a stronger relationship between career commitment and career success, while lower levels of positive framing lead to a weaker relationship between career commitment and career success and thus, the 2(b) has been accepted.

\section{Discussion and Conclusion}

This study aimed to identify the influence of career commitment on subjective career success and the moderator role of positive framing on this relationship. As expected, the findings of this study indicated that career commitment positively influences subjective career success. This finding substantiates the results of previous studies that explored the positive influence of career commitment on career success (Ballout, 2009; Day and Allen, 2004; Pathardikar et al., 2016; Poon, 2004). This finding indicated that individuals who make 
significant investments in their careers and put considerable effort in achieving their career goals are more likely to succeed in their careers. Further, this study explored that employees' engagement in positive framing moderate the relationship between career commitments and career success and this relationship is stronger those who engage in a high level of positive framing than those who engage in the low level of positive framing. These findings suggest that employees who exhibit more significant career commitment with high positive framing are more likely to succeed in their career than those who exhibit high career commitment with less positive framing. Employees with high positive framing interpreting the situation and events as an opportunity than threats or obstacles (Ashford and Black, 1996; Owens, 2010) and such interpretations help them to feel a positive energy and increase their resources though the actual situation is as it is. Therefore individuals who exhibit a high level of career commitment with a high level of positive framing can experience more career success than others.

In today's career environment that forces individuals to take responsibility for their career success individual-level resources that energize individuals has become more important for career success than before (Ballout, 2009; Lyons et al., 2015). Though existing literature highlights the moderator effect of emotional intelligence, self-efficacy (Ballout, 2009; Sultana et al., 2016) on the positive influence of career commitment on career success empirical research is lacking, especially the moderating role of positive framing in career research. So by including positive framing as a moderator variable, the present study enhances existing career-related research that examining the relationship between career commitment and career success.

\subsection{A Theoretical and Practical Contribution}

Though previous studies have explored the positive influence of career commitment on career success, this study, by verifying the moderator effect of positive framing (cognitive self-management process) on this relationship extends the career literature. This study suggests that individuals who exhibit strong career commitment and a 
higher positive framing achieve more subjective career success. In the present career context where individuals are responsible for their career, highlighting the moderating role of their cognitive selfmanagement process on the career commitment and career success relationship is significant to the career literature and practice.

Consequences of career success are favorable to both the organization and individuals (Ballout, 2009; Vandenberghe and Ok, 2013; Pasha et al., 2017; Sultana et al., 2016), and this study provides valuable suggestions to both of them. As an organization could not take the responsibility of employees' career success, it can support them (Hall and Moss, 1998). It can provide an appropriate organizational culture that enables employees to make an outstanding investment in their career and put considerable effort in achieving their career goals (Goulet and Singh, 2002; London, 1983). Further, an organization can select self-motivated employees, best fit for the job and the organization, and have the right attitudes (Randall, 1987) to enhance their career commitment and career success. Further, an organization can facilitate employees to participate in training programs related to attitude change and self -management processes that enable individuals to engage in positive framing.

In the current career context where individuals are required to selfmanage their career and be more committed to their career than to their organization (Ballout, 2009; Sultana et al., 2016) the findings of this study are significant to employees also. The results of this study advise the employees to develop their personal career goals and involve in these goals (Blau, 1988). Also, this study suggests, in addition to the career commitment, employees have to develop their self-management process in an optimistic way to achieve their career success. In addition to career success, individual's engagement in positive framing increases one's own resources (Ashford \& Black, 1996; Saks \& Gruman, 2012), and such resources help individuals to assimilate more resources and overcome stress and challenges (Hobfoll, 2002; Saks \& Gruman, 2012). Therefore, by engaging in positive framing, employees can enjoy several benefits in addition to career success. 


\subsection{Limitations and Further Research}

The contribution of this study is significant; however, it is essential to note that it has a couple of limitations. First, though data were collected from employees from different industries, these data were merged and considered as a single sample for the analysis. As the sample was drawn from several sectors, and the number of responses from each industry widely differ researcher could not statistically test the hypotheses for each industry. Therefore, this study could not provide industry-specific suggestions. Second, this study is selfreported, which is prone to common method variance (CMV). However, reported CMV in career research is less prevalent (Ballout, 2009; Crampton and Wagner, 1994). Further, as this study includes the interaction effect of the moderator variable CMV may not be a significant issue in this study (Erdogan and Bauer, 2005). Third, as this study is cross-sectional, it limits the interpretation of causal relationships proposed in this study. Finally, this study includes only one country sample, and it limits the generalizability of the findings.

Conducting further research with a longitudinal design may capture employees' career commitment and career success over the time period. Further, the same study could be done in different countries/contexts to confirm the validity of the present findings. This study proposed that both career commitment and positive framing leads to career success; however, career success may affect career commitment (Ballout, 2009). Therefore, further studies can be directed to examine this relationship using a different research approach (qualitative). There are significant differences between public sector organizations and private sector organizations in careerrelated policies (for example, promotion and salary) and the nature of employment relationships. Therefore, conducting further careerrelated research with a sample of both private and public-sector organizations and comparing the findings will give more insights into the career research. 


\section{References}

Abele, A. E., and Spurk, D. (2009). The longitudinal impact of selfefficacy and career goalson objective and subjective career success. Journal of Vocational Behavior, Vol. 74 No. 1, pp. $53-62$.

Arthur, M.B., Khapova, S.N. and Wilderom, C.P. (2005). Career success in a boundaryless career world. Journal of Organizational Behavior, Vol. 26 No. 2, pp. 177-202.

Ashford, S. J., \& Black, J. S. (1996). Proactivity during organizational entry: The role of desire for control. Journal of Applied Psychology, Vol. 81 No. 2, pp. 199-214

Ashford, S. J., \& Taylor, M. S. (1990). Adaptation to work transitions: An integrative approach. Research in Personnel and Human Resources Management, Vol. 8 No. 1, pp. 1-39.

Ashforth, B. E., \& Saks, A. M. (1995). Work-role transitions: A longitudinal examination of the Nicholson model. Journal of Occupational and Organizational Psychology, Vol. 68 No. 2, pp. 157-175.

Ashforth, B. E., Sluss, D. M., \& Saks, A. M. (2007). Socialization tactics, proactive behavior, and newcomer learning: Integrating socialization models. Journal of Vocational Behavior, Vol. 70 No. 3, pp. 447-462.

Ashforth, B. K., \& Saks, A. M. (1996). Socialization tactics: Longitudinal effects on newcomer adjustment. Academy of management Journal, Vol. 39 No. 1, pp. 149-178.

Ballout, H.I. (2009). Career commitment and career success: moderating role of self-efficacy. Career Development International, Vol. 14 No. 7, pp. 655-670. 
Baruch, Y. (2006). Career development in organizations and beyond: Balancing traditional and contemporary viewpoints. Human Resource Management Review, Vol. 16 No. 2, pp. 125-138.

Blau, G.L. (1985). Measurement and prediction of career commitment. Journal of Occupational Psychology, Vol. 58 No. 4, pp. 277-288.

Carson, K.D., Carson, P.P., Roe, C.W., Birkenmeier, B.J. and Phillips, J.S. (1999). Four commitment profiles and their relationships to empowerment, service recovery, and work attitudes. Public Personnel Management, Vol. 28, pp. 1-13.

Colarelli, S.M. and Bishop, R.C. (1990). Career commitment: functions, correlates, and management. Group \& Organization Studies, Vol. 15 No. 2, pp. 158-76.

Crampton, S.M. and Wagner, J.A. (1994). Percept-percept inflation in micro organizational research: an investigation of prevalence and effect. Journal of Applied Psychology, Vol. 79 No. 1, pp. 67-76.

Day, R. and Allen, T. (2004). The relationship between career motivation and self-efficacy with prote 'ge' career success. Journal of Vocational Behavior, Vol. 64, pp. 72-91.

Erdogan, B. and Bauer, T.N. (2005). Enhancing career benefits of employee proactive personality: the role of fit with jobs and organizations. Personnel Psychology, Vol. 58, pp. 859-91.

Gattiker, U.E. and Larwood, L. (1984). Career success: an exploratory study of managers reports. available at: https://files.eric.ed.gov/fulltext/ED286099.pdf

Goulet, L.R. and Singh, P. (2002). Career commitment: a reexamination and an extension. Journal of Vocational Behavior, Vol. 61 No. 1, pp. 73-91 
Greenhaus, J., Parasuraman, S. and Wormley, W. (1990). Effects of race on organizational experiences, job performance evaluations, and career outcomes. Academy of Management Journal, Vol. 33 No. 1, pp. 64-86.

Griffin, A. E., Colella, A., \& Goparaju, S. (2001). Newcomer and organizational socialization tactics: An interactionist perspective. Human Resource Management Review, Vol. 10 No. 4, pp. 453-474.

Gruman, J. A., Saks, A. M., \& Zweig, D. I. (2006). Organizational socialization tactics and newcomer proactive behaviors: An integrative study. Journal of Vocational Behavior, Vol. 69 No. 1, pp. 90-104.

Hair, J. F., Ringle, C. M., \& Sarstedt, M. (2011). PLS-SEM: Indeed a silver bullet. The Journal of Marketing Theory and Practice, Vol. 19 No. 2, 19(2), pp.139-152.

Hair, J. F., Hult, G. T. M., Ringle, C. M., \& Sarstedt, M. (2017). A Primer on Partial Least Squares Structural Equation Modeling. 2nd Ed. Thousand Oaks: Sage.

Hall, D. (1971). A theoretical model of career sub-identity development in organizational settings. Organizational Behavior and Human Performance, Vol. 6, pp. 50-76.

Hall, D.T. (1996). Protean careers of the 21st century. Academy of Management Executive, Vol. 10 No. 4, pp. 8-16.

Hall, D.T. (2004). The protean career: a quarter-century journey. Journal of Vocational Behavior, Vol. 65 No. 1, pp. 1-13.

Hobfoll, S. E. (2002) Social and psychological resources and adaptation. Review of General Psychology, Vol. 6 No.4, pp. 307.

Ishak, S. (2015). Career success studies: an examination of indicators, approach and underlying theories in literature. 
Science Journal of Business and Management, Vol. 3 No. 6, pp. 251-257.

James, R. (2019). Repatriates' Work Engagement: Proactive Behavior, Perceived Support, and Adjustment. Journal of Career

Development,https://doi.org/10.1177/0894845319886104

James, R. and Azungah, T. (2019). Repatriation of academics: organizational support, adjustment and intention to leave. Management Research Review, Vol. ahead-of-print No. ahead-of-print. https://doi.org/10.1108/MRR-04-2019-0151

Judge, T., Cable, D., Boudreau, J. and Bretz, R. (1995). An empirical investigation of the predictors of executive career success. Personnel Psychology, Vol. 48, pp. 485-519.

Kidd, J.M. and Green, F. (2006). The careers of research scientists: predictors of three dimensions of career commitment and intention to leave science. Personnel Review, Vol. 35 No. 3, pp. 229-51.

Kim, M. and Beehr, T.A. (2017). Directing our own careers, but getting help from empowering leaders. Career Development International, Vol. 22 No. 3, pp. 300-317.

Kim, T., Cable, D. M., \& Kim, S. (2005). Socialization tactics, employee proactivity, and person-organization fit. Journal of Applied Psychology, Vol. 9 No. 2, pp. 232-241.

King, Z. (2004). Career self-management: its nature, causes and consequences. Journal of Vocational Behavior, Vol. 65 No. 1, pp. 112-33.

Kowsikka, F. M. J. J., \& James, R. (2019). Newcomers' socialization: the proactive behaviors, satisfaction and social integration. Journal of Business Studies, Vol. 6 No. 1, pp. 107-124. 
London, M. (1983). Toward a theory of career motivation. Academy of Management Review, Vol. 8 No. 4, pp. 620-30.

Luo, Q, Wang, C. and Han, J. (2018). Model structure on self efficacy and career success of it engineers. Journal of Physics: Conf. Series, Vol.1069 No.1, p.012005.

Luthans, F., Youssef, C. M., \& Avolio, B. J. (2006). Psychological capital: Developing the human competitive edge. Oxford University Press.

Lyons, S.T., Schweitzer, L. and Ng, E.S. (2015). How have careers changed? An investigation of changing career patterns across four generations. Journal of Managerial Psychology, Vol. 30 No. 1 , pp. 8-21.

Moon, J.S. and Choi, S.B. (2017). The impact of career management on organizational commitment and the mediating role of subjective career success:

Nabi, G. (2003). Situational characteristics and subjective career success: the mediating role of career-enhancing strategies. International Journal of Manpower, Vol. 24 No. 6, pp. 653671.

Ng, T.W.H., Eby, L.T., Sorensen, K.L. and Feldman, D.C. (2005). Predictors of objective and subjective career success: A metaanalysis. Personnel Psychology, Vol. 58 No. 2, pp. 367-408.

Owen, J. J. (2010). Assessing the factor structures of the 55-and 22item versions of the Conformity to Masculine Norms Inventory. American Journal of Men's Health. doi: $10.1177 / 1557988310363817$

Park, Y. (2010). The predictors of subjective career success: An empirical study of employee development in a Korean financial company. International Journal of Training and Development, Vol. 14 No. 1, pp. 1-15. 
Pasha, A.T., Hamid, K.A. and Shahzad, A. (2017). Mediating role of career commitment in the relationship of promotional opportunities, rewards and career success. Pakistan Journal of Statistics and Operation Research, Vol. 13 No. 1, pp. 185199.

Pathardikar, A.D., Sahu, S. and Jaiswal, N.K. (2016). Assessing organizational ethics and career satisfaction through career commitment. South Asian Journal of Global Business Research, Vol. 5 No. 1, pp. 104-124.

Poon, J.M.L., (2004). Career commitment and career success: Moderating role of emotion perception. Career Development International, Vol. 9 No. 4, pp. 374-390.

Punnett, B.J., Duffy, J.A., Fox, S., Gregory, A., Lituchy, T., Miller, J., Inés Monserrat, S., Olivas-Luján, M.R. and Bastos F. Santos, N.M. (2007). Career success and satisfaction: a comparative study in nine countries. Women in Management Review, Vol. 22 No. 5, pp. 371-390.

Saks, A. M., \& Ashforth, B. E. (1996). Proactive socialization and behavioral self-management. Journal of Vocational Behavior", Vol. 48 No. 3, pp. 301-323.

Saks, A. M., \& Gruman, J. A. (2012). Getting newcomers on board: A review of socialization practices and introduction to socialization resources theory. In C. Wanberg (Ed.), The Oxford Handbook of Organizational Socialization (pp 27-55). New York: Oxford University Press Inc.

Seibert, S.E., Kraimer, M.L. and Crant, J.M. (2001). What do proactive people do? A longitudinal model linking proactive personality and career success. Personnel Psychology, Vol. 54No. 4, pp. 845-874.

Spurk, D., Hirschi, A. and Dries, N. (2019). Antecedents and outcomes of objective versus subjective career success: 
competing perspectives and future directions. Journal of Management, Vol. 45 No. 1, pp. 35-69.

Sultana, R., Yousaf, A., Khan, I. and Saeed, A. (2016). Probing the interactive effects of career commitment and emotional intelligence on perceived objective/subjective career success. Personnel Review, Vol. 45 No. 4, pp. 724-742.

The case of Korean R\&D employees. Journal of Career Development, Vol. 44 No.3, pp. 191-208.

Vandenberghe, C. and Basak Ok, A. (2013) Career commitment, proactive personality, and work outcomes: A cross-lagged study. Career Development International, Vol.18 No. 7, pp. 652-672.

Wanberg, C. R., \& Kammeyer-Mueller, J. D. (2000). Predictors and outcomes of proactivity in the socialization process. Journal of Applied Psychology, Vol. 85 No. 3, pp. 373-385.

Wang, P., Sang, J., Li, P. and Zhao, J. (2016). How to make a newcomer happy? The mediating role of career commitment on the relationship between unmet expectations and job satisfaction. Social Indicators Research, Vol. 127 No. 1, pp. 401-412. 